\title{
Uso e ocupação do entorno do reservatório público do município de Riacho da Cruz (RN)
}

\section{Uso e ocupación al rededor del embalse público del município de Riacho da Cruz (RN)}

\section{Use and Occupation on the Surroundings at Riacho da Cruz Public Reservoir (RN)}

Francisca Wigna da Silva Freitas

wignagreitas@yahoo.com.br

Universidade do Estado do Rio Grande do Norte, UERN, Campus de Pau dos Ferros, RN

Josiel de Alencar Guedes

josielguedes@uern.br

Universidade do Estado do Rio Grande do Norte, UERN, Campus de Assú, RN

Resumo: O presente artigo tem por objetivo analisar os usos e ocupação no entorno do reservatório público do município de Riacho da Cruz (RN), como forma de discutir o planejamento e gestão de recursos hídricos. A partir da utilização do Sistema de Informação Geográfico (SIG), utilizou-se o software Qgis v. 2.14.11) para a classificação visual de imagens, por meio da fotointerpretação, e vetorização. Para construção do mapa de uso e ocupação da área considerou-se um buffer de 500m do entorno do reservatório. Identificou-se no entorno do reservatório as classes, mata nativa (69\%), vegetação rasteira/rala (5,7\%), área urbanizada (3,2\%), entre outros. Observou-se que a presença urbana no entorno do reservatório pode interferir na sua qualidade. Dessa forma, torna-se relevante o planejamento e gestão dessa área para minimizar os impactos das ações antrópicas e auxiliar no manejo integrado do ambiente.

Palavras-chave: Recursos Hídricos, Uso da terra, Semiárido.

Resumen: El presente artículo tiene por objetivo analizar los usos y ocupación en el entorno del reservorio público del municipio de Riacho da Cruz (RN), como forma de discutir la planificación y gestión de recursos hídricos. A partir de la utilización del Sistema de Información Geográfico (SIG), se utilizó el software Qgis v. 2.14.11 para la clasificación visual de imágenes, por medio de la fotointerpretación, y vectorización. Para construcción del mapa de uso y ocupación del área si consideró un buffer de $500 \mathrm{~m}$ del entorno del embalse. Si identificó las clases mata nativa $(69 \%)$, vegetación rastrera / rala $(5,7 \%)$, área urbanizada $(3,2 \%)$, entre otros. Si observó que la presencia urbana en el entorno del embalse puede interferir en su calidad. De esta forma, se hace relevante la planificación y gestión de esa área para minimizar los impactos de las acciones antrópicas y auxiliar en el manejo integrado del ambiente.

Palabras-clave: Recursos hídricos, Uso de la tierra, Semiárido

Abstract: This paper aims to analyze the use and occupation on the surroundings of the public reservoir of the municipality of Riacho da Cruz (RN), in order to discuss the planning and management of water resources. Visual classification of images 
were performed by Geographic Information System (GIS), employing the software Qgis v. 2.14.11 for photointerpretation, and vectorization. To make the map of use and occupation it was considered a $500 \mathrm{~m}$ buffer from the reservoir edge. It were identified the classes native forest (69\%), lowland vegetation (5.7\%), urbanized area $(3.2 \%)$, among others. It was observed that the urban presence in the surroundings could interfere in the reservoir quality. Therefore, it is relevant to plan and manage this area to minimize the impacts of anthropic actions and to assist in the integrated environment management.

Key words: Water resources, Land use, Semiarid.

\section{INTRODUÇÃO}

O desenvolvimento econômico, o crescimento demográfico e o uso dos recursos naturais, ao longo dos anos, pode modificar a dinâmica natural do meio, na interferência dos sistemas ambientais, e possibilita reflexos negativos para o ambiente natural e social (DIAS, 2009).

Os recursos naturais, em particular os hídricos, são essenciais para o desenvolvimento natural, econômico e social e para as atividades econômicas como a agricultura e a pecuária, entre outras (TUNDISI et al., 2006). A partir de meados do século XIX, políticas públicas desenvolvidas pela Superintendência de Desenvolvimento do Nordeste (SUDENE) e o Departamento de Obras Contra a Seca (DNOCS) levaram à construção de reservatórios superficiais visando o abastecimento, irrigação e pesca no semiárido brasileiro. Este apresenta um contexto favorável à construção de reservatórios de armazenamento de água devido a sua série histórica de precipitações acumuladas e a geologia predominante do Cristalino (MOLLE; CADIER, 1998).

A discussão sobre planejamento e gestão nas bacias hidrográficas é de competência dos comitês de bacia, que juntamente com as esferas de planejamento nacional, estadual, municipal, e a comunidade, buscam estabelecer medidas de manejos sustentáveis, no desenvolvimento da governança ambiental (CUNHA; COELHO, 2009). A delimitação de bacias e microbacias e a construção de reservatórios frequentemente ultrapassa limites municipais, estaduais ou nacionais, o que aponta para a importância das discussões dos comitês de bacia para buscar a conservação e a sustentabilidade socioeconômica, de forma integrada aos agentes modificadores, buscando o desenvolvimento e minimizando os conflitos sociais e impactos sobre os recursos disponíveis na região (CUNHA; COELHO, 2009).

Os conflitos por recursos naturais são amplos e estão vinculados a captação, distribuição, recarga e posse do recurso. Em relação aos recursos hídricos "torna-se evidente que, nessas condições da distribuição hídrica na superfície do planeta, surgem disputas e interesses por territórios onde haja disponibilidade hídrica e recarga de aquíferos" (MAURO, 2014, p.83), em que se necessita de aporte legislativo para conservar e gerir recursos com sustentabilidade. A Lei No 9.433/1997 (BRASIL, 1997) discorre sobre os usos 
dos recursos hídricos e ações que possam afetar a quantidade e qualidade da água, destacando a bacia hidrográfica como unidade de planejamento e a necessidade de planejamento e gestão participativa como forma de minimizar os efeitos das ações antrópicas no meio. Igualmente descreve a relevância da descentralização da gestão, referente aos recursos hídricos, buscando auxílio nos agentes locais para a conservação, delimitando ações que possam de forma integrada utilizar os recursos com um mínimo de impactos. Destacase também a Lei Florestal (BRASIL, 2012), como legislação que subsidia o planejamento e gestão de recursos ao dispor sobre a proteção das matas nativas no entorno de corpos hídricos e as formas de uso permitidos.

Assim, a necessidade de desenvolver ações que buscam a melhoria dos reservatórios e o uso de seu entorno, geram discussões sobre a qualidade ambiental desses mananciais (ROSA et al., 2015). A forma de manejo obviamente influência na qualidade do recurso, sendo necessário buscar ferramentas para analisar, caracterizar e diagnosticar os ambientes, buscando apontamentos relevantes para delimitar e propor medidas para as formas de uso e ocupação. Portanto, compreender os impactos do manejo em áreas de reservas hídricas possibilita apontar medidas que venham amenizar os impactos atingir um equilíbrio entre desenvolvimento e conservação (ALUIZO JR.; GUEDES, 2016; FREITAS; GUEDES; COSTA, 2016; NASCIMENTO; GUEDES, 2016).

Diagnósticos socioambientais, caracterizações e análises de uso e ocupação em reservatórios, microbacias e bacias hidrográficas ao longo das últimas décadas construíram um aporte teórico-metodológico de estudos integrados de sistemas ambientais, com subsídios à legislação, gestão e planejamento (ROSA et al., 2015; ALUIZO JR.; GUEDES, 2016; FREITAS; GUEDES; COSTA 2015; 2016; GUEDES; COSTA, 2017). Dessa forma, este artigo pretende analisar o uso e ocupação do reservatório público do município de Riacho da Cruz (RN) como subsídio a discussão das formas de manejo do solo que influenciam no desenvolvimento socioeconômico da área e seus reflexos regionais.

\section{MATERIAIS E METÓDOS}

\section{Área da pesquisa}

O município de Riacho da Cruz tem $127,223 \mathrm{Km}^{2}$ de extensão territorial, e uma população de 3.165 habitantes, com densidade demográfica de 24,88 hab./ $\mathrm{Km}^{2}$ e Índice de Desenvolvimento Humano por município (IDHM) de 0,584 (IBGE, 2012).

O município está inserido, na Província Borborema, com litotipos dos complexos Jaguaretama e Caicó, da suíte Calcialcalina de Médio a Alto Potássio Itaporanga, entre 100 e 200 metros de altitude, localizados na Depressão Sertaneja, configurando-se entre as partes altas do Planalto da Borborema e da Chapada do Apodi. A vegetação predominante é a caatinga hiperxerófila, composta por vegetação arbustiva e rala apresentando-se principalmente com cactáceas e bromeliáceas, com espécies como jurema preta (Mimosa tenuiflora), mufumbo (Combretum laxum), faveleiro (Cnidoscolus quercifolius), marmeleiro 
(Cydonia oblonga) e xique-xique (Pilosocereus polygonus). O clima semiárido é caracterizado por duas estações definidas, o inverno e verão, e apresenta o período chuvoso entre os meses de fevereiro e abril, com precipitação média de 700 (mm) ao ano (CPRM, 2005).

O reservatório público do município (Fig. 1), também conhecido como Riacho da Cruz II, está inserido no médio curso da bacia do rio Apodi-Mossoró e foi construído pelo DNOCS em 1957. A bacia do reservatório possui uma área de $1.138 \mathrm{Km}^{2}$ e volume hídrico máximo de $9.604 .200 \mathrm{~m}^{3}$ e mínimo de $632.700 \mathrm{~m}^{3}$ (SEMARH, 2016).

Figura 1. Localização do reservatório público Riacho da Cruz II.

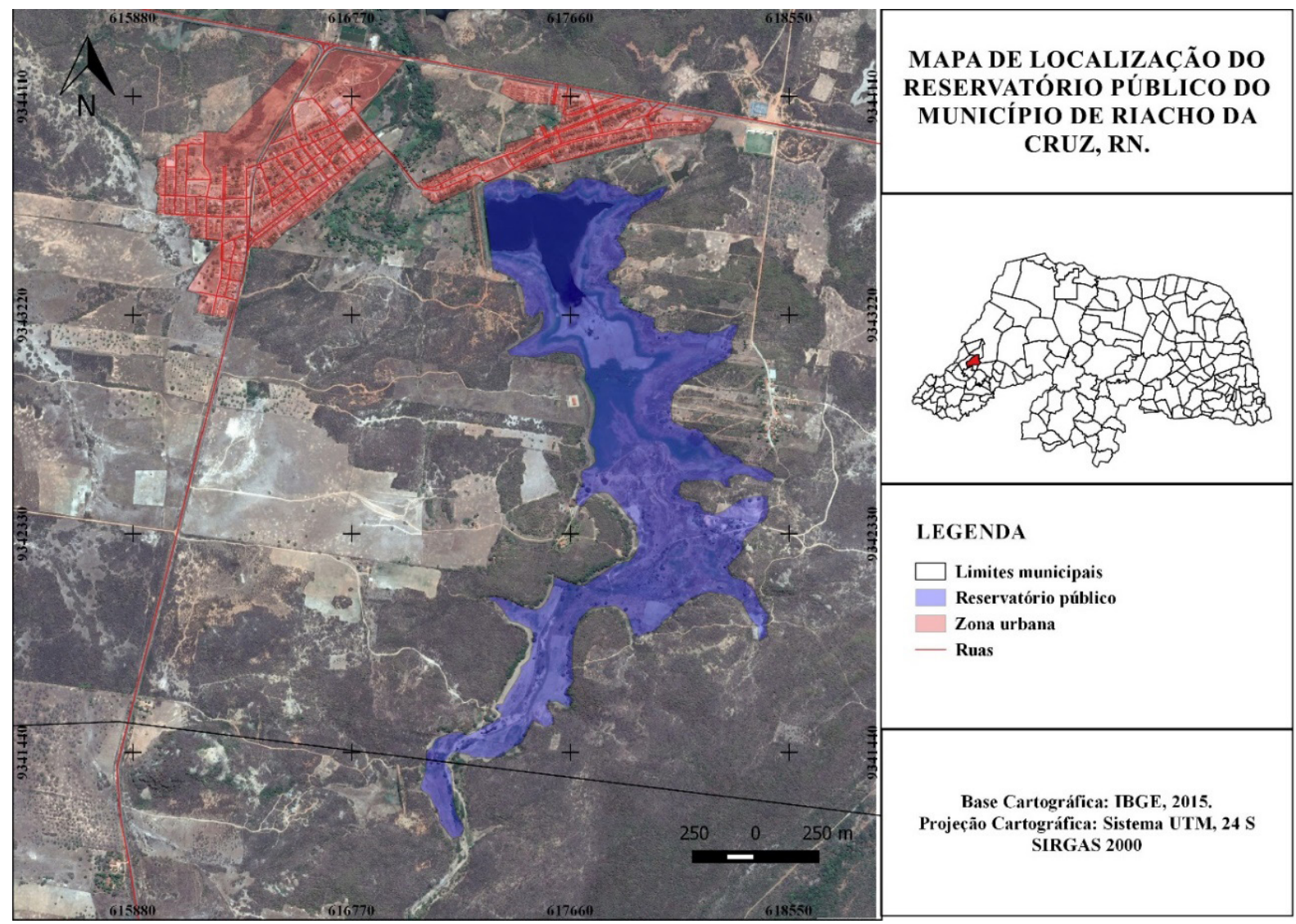

Fonte: IBGE (2015), mod. pelos autores.

\section{Procedimentos metodológicos}

A metodologia de pesquisa do uso e ocupação do reservatório se deu em duas etapas (Fig. 2) que envolveram atividade de laboratório e campo para a delimitação e análise do uso do entorno do reservatório.

A primeira etapa consistiu de levantamento bibliográfico e de informações sobre a área da pesquisa a partir da construção de dados primários e coleta de dados secundários. Na segunda etapa foram trabalhadas imagens digitais em laboratório utilizando-se de ferramentas do Sistema de Informação Geográfica (SIG) por meio do software QGIS v.2.14.11, que possibilitou delimitar e classificar o uso e as formas de ocupação do entorno. 
Para a classificação do uso foi utilizado shape da hidrografia da região oeste do Rio Grande do Norte para delimitar o reservatório, e das imagens raster TOPO DATA da hipsometria da área para delimitação das redes de drenagem.

A delimitação do entorno do reservatório se deu por meio da delimitação vetorial de um buffer de 500 metros junto ao perímetro do shape do reservatório. Neste foram identificados-os agentes modeladores da paisagem, e localizadas as comunidades residentes no entorno do reservatório.

Figura 2: Fluxograma das etapas metodológicas.

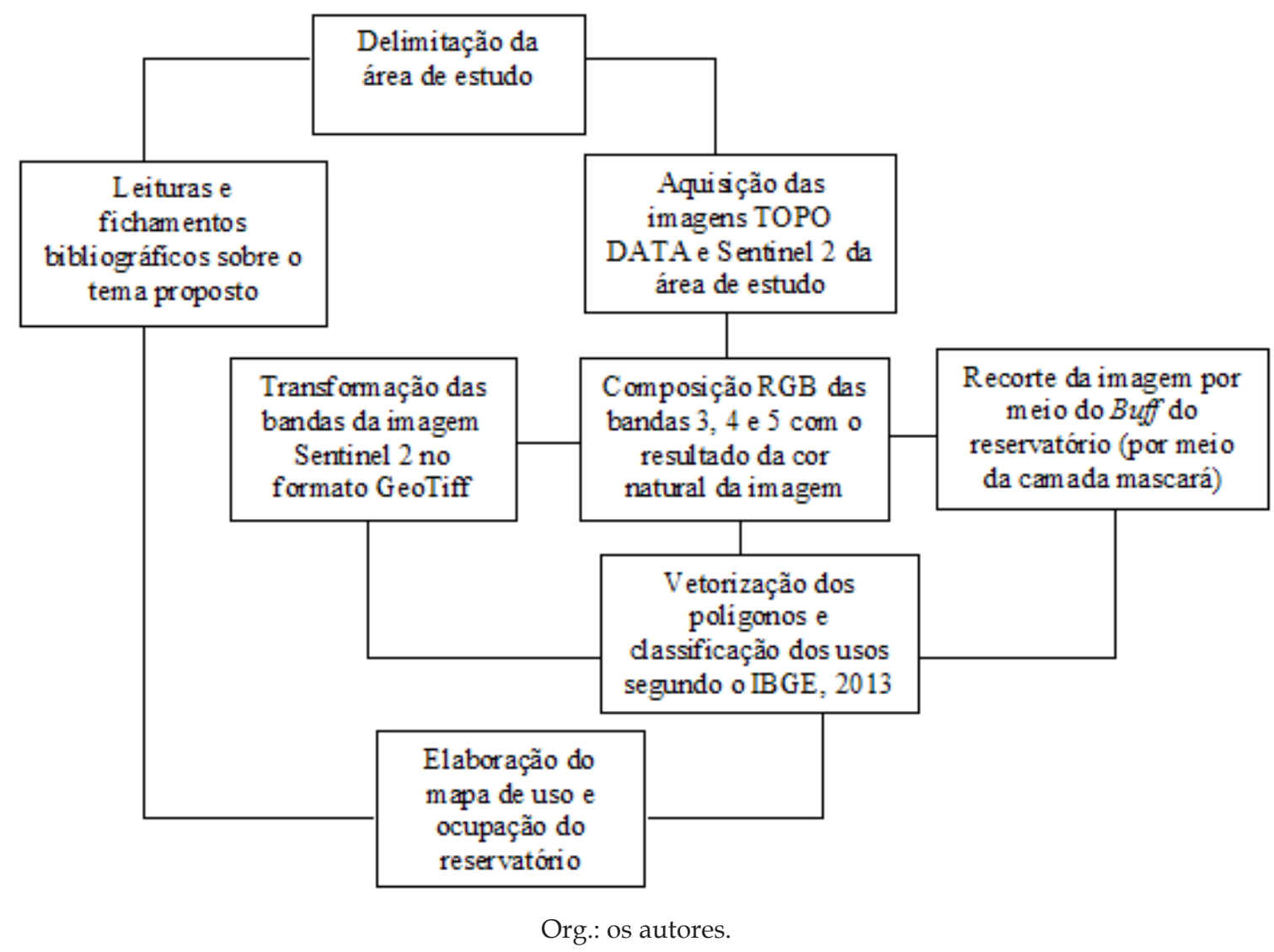

Para a delimitação do uso na área do buffer foi utilizado a imagem orbital do satélite Sentinel-2 com resolução de $10 \mathrm{~m}$, disponibilizadas pela U.S. Geological Survey Earth Explorer (USGS), como base para a classificação do uso e ocupação da área.

A vetorização das classes de uso e ocupação do solo ocorreu por meio da classificação manual de imagens, por meio da fotointerpretação (PARANHOS FILHO et al., 2016), a partir da composição colorida da imagem Sentinel-2. No software Qgis foi possível essa composição por meio da ferramenta raster na miscelânea para realizar o mosaico das bandas (B02; B03; B04; B08), para gerar a cor natural da paisagem realizando a combinação RGB (Red - Green - Blue) das bandas (Quadro 1). 
Quadro 1: Composição colorida da imagem de satélite Sentinel-2.

\begin{tabular}{|c|c|c|c|c|}
\hline Resolução & No. da banda & Nome das bandas & $\begin{array}{l}\text { Comprimento da onda } \\
\text { central (nanômetro) }\end{array}$ & Combinações das bandas \\
\hline \multirow[t]{4}{*}{$10 \mathrm{~m}$} & B02 & Blue (azul) & 490 & \multirow{4}{*}{$\begin{array}{l}\text { Cor verdadeira } \\
\text { RGB 04/03/02 } \\
\text { Falsa Cor } 1 \text { e } 2 \\
\text { RGB 08/04/03 e 04/08/03 }\end{array}$} \\
\hline & B03 & Green (verde) & 560 & \\
\hline & B04 & Red (vermelho) & 665 & \\
\hline & B08 & NIR (infravermelho próximo) & 842 & \\
\hline
\end{tabular}

Fonte: Processamento Digital (2017), adapt. pelos autores.

Com a composição RGB da imagem teve início a vetorização e posterior classificação das classes de uso com base no Manual técnico do uso da terra (IBGE, 2012).

Dessa forma, após a vetorização dos usos em laboratório foi realiza a visita em campo em maio de 2016, período em que o reservatório apresentou capacidade mínima de água, para o georeferrenciamento empregando GPS - Global Positioning System (Quadro 2), e para verificar a veracidade dos dados observados em ambiente computacional.

Quadro 2: Descrições dos pontos de controle no entorno do reservatório Riacho da Cruz II.

\begin{tabular}{|c|c|c|c|}
\hline Pontos & $\begin{array}{l}\text { Coordenas } \\
\text { (UTM) }\end{array}$ & Registro fotográfico & Descrição \\
\hline 01 & $\begin{array}{l}\text { Y } 0587758 \\
\text { X } 9322180\end{array}$ & & $\begin{array}{l}\text { Margem esquerda. Caatinga preservada com vegetação } \\
\text { densa. Apresentando em suas proximidades cultivos } \\
\text { de milho, capim, sorgo, entre outros. }\end{array}$ \\
\hline 02 & $\begin{array}{l}\text { Y } 0618021 \\
\text { X } 9342712\end{array}$ & & $\begin{array}{l}\text { Leito seco do riacho principal com cultivo de capim } \\
\text { (capineiras). }\end{array}$ \\
\hline 03 & $\begin{array}{l}\text { Y } 0618038 \\
\text { X } 9342826\end{array}$ & & Margem direita. Vegetação rasteira e espaçada. \\
\hline 04 & $\begin{array}{l}\text { Y } 0617921 \\
\text { X } 9342424\end{array}$ & & $\begin{array}{l}\text { Margem esquerda, com destaque para a mineração de } \\
\text { areia. }\end{array}$ \\
\hline
\end{tabular}


conclusão

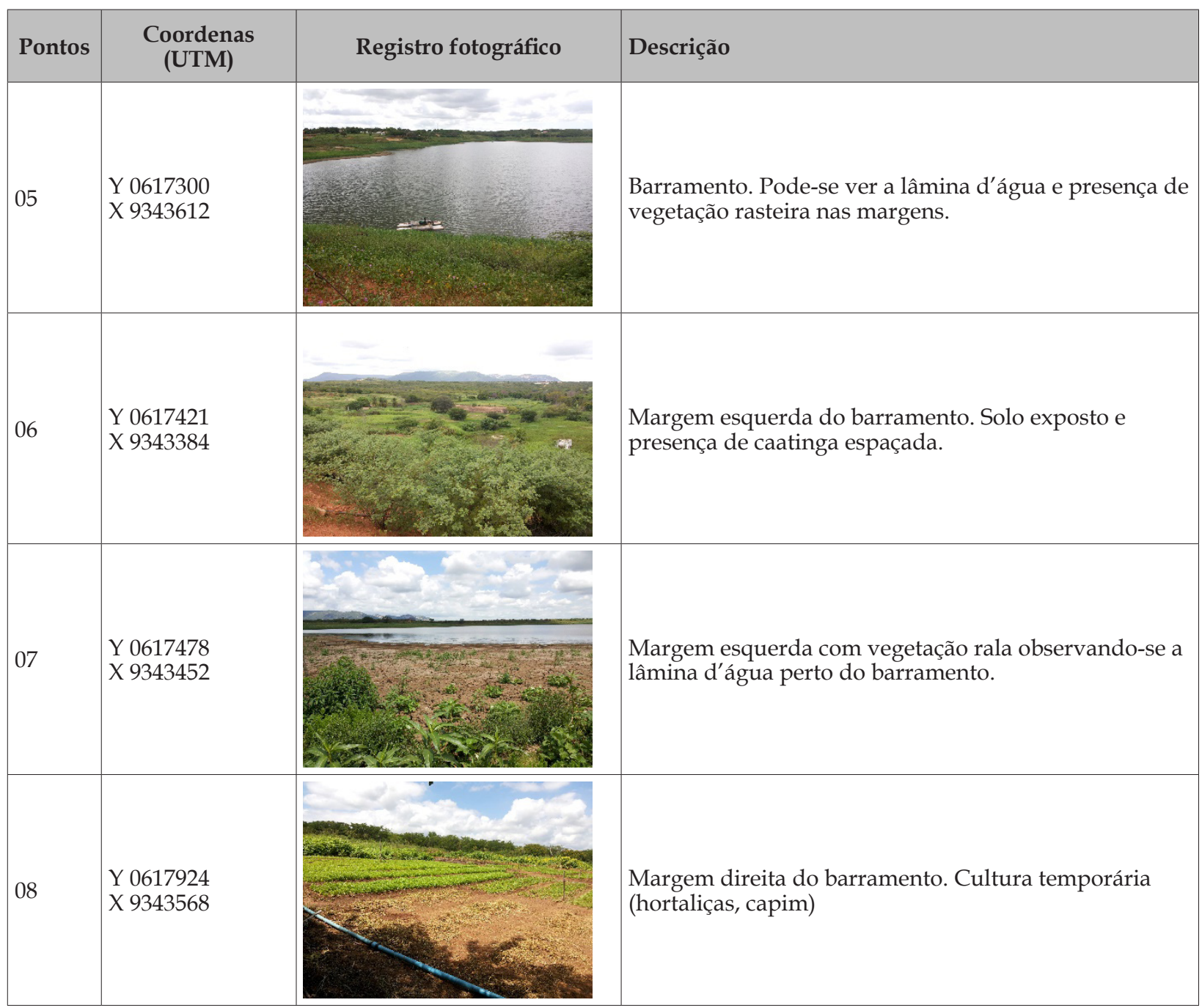

Fonte: os autores.

\section{RESULTADOS E DISCUSSÕES}

O uso e a ocupação humana estão associados às diferentes ações que implicam na qualidade ambiental de mananciais superficiais, especialmente os reservatórios de água, principalmente em áreas com déficit ou escassez de água, com problemas gerados pela ausência de planejamento e gestão desses recursos (FREITAS; GUEDES; COSTA, 2015, 2016; BEZERRA JR; GUEDES, 2016; BRITO; GUEDES, 2016; NASCIMENTO; GUEDES, 2016).

No entorno delimitado pelo buffer foi possível observar, além do componente hídrico, os seguintes usos: culturas permanentes, culturas temporárias, mata nativa, vegetação rasteira/rala, área sem cobertura, comunidade rural e área urbanizada (Tab. 1, Quadro 3, Fig. 3). 
Tabela 1: Área ocupada pelas classes de uso no entorno do Reservatório Riacho da Cruz II, RN.

\begin{tabular}{l|c|c}
\multicolumn{1}{c|}{ Uso e Ocupação } & Área em $\mathrm{Km}^{2}$ & $\%$ \\
\hline Cultura permanente & 0,055 & 0,86 \\
\hline Cultura temporária & 0,093 & 1,46 \\
\hline Mata nativa & 4,418 & 69,14 \\
\hline Vegetação rasteira/rala & 0,364 & 5,69 \\
\hline Área sem cobertura & 0,047 & 0,73 \\
\hline Comunidade Aracajú & 0,041 & 0,65 \\
\hline Área urbanizada & 0,206 & 3,22 \\
\hline Corpos hídricos & 0,040 & 0,63 \\
\hline Reservatório & 1,126 & 17,62 \\
\hline Total & 6,390 & 100,00 \\
\hline
\end{tabular}

Fonte: os autores.

Figura 3: Mapa de uso e ocupação do entorno do reservatório.

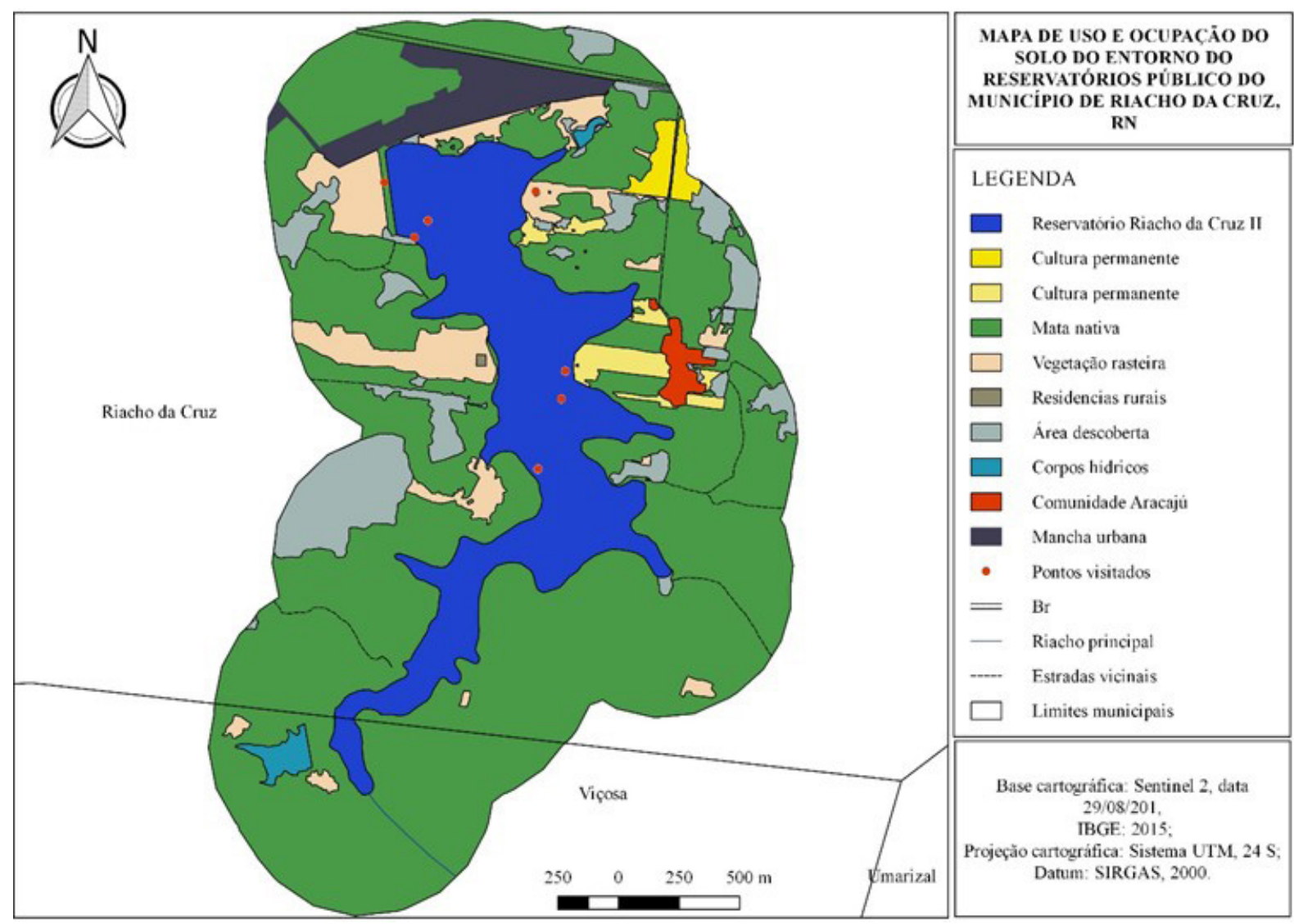

Fonte: Imagem Sentinel-2, data 29/08/2016; IBGE (2015). Elab. pelos autores. 
Quadro 3: Descrição das classes utilizados no entorno do reservatório.

\begin{tabular}{|l|l|}
\hline Classes & Descrição \\
\hline Cultura permanente & Compreende o cultivo de plantas perenes, isto é, de ciclo vegetativo de longa duração. \\
\hline Cultura temporária & $\begin{array}{l}\text { É o cultivo de plantas de curta ou média duração, geralmente com ciclo vegetativo } \\
\text { inferior a um ano, que após a produção deixam o terreno disponível para novo plantio. }\end{array}$ \\
\hline Áreas sem cobertura & $\begin{array}{l}\text { Áreas de extração de areia abandonadas e sem cobertura vegetal; áreas compostas pela } \\
\text { matriz rochosa exposta. }\end{array}$ \\
\hline Áreas urbanizadas & $\begin{array}{l}\text { Como situação urbana foram consideradas as áreas correspondentes às cidades (sedes } \\
\text { municipais), às vilas (sedes distritais) e às áreas urbanas isoladas conforme classificação } \\
\text { do IBGE. }\end{array}$ \\
\hline Corpos hídricos & $\begin{array}{l}\text { Os continentais referem-se aos corpos d'água naturais e artificiais que não são de } \\
\text { origem marinha, tais como: rios, canais, lagos e lagoas de água doce, represas, açudes, } \\
\text { etc. }\end{array}$ \\
\hline Vegetação rasteira/rala & $\begin{array}{l}\text { É a área destinada ao pastoreio do gado, formada mediante plantio de forragens } \\
\text { perenes ou aproveitamento e melhoria de pastagens naturais. Nestas áreas, o solo está } \\
\text { coberto por vegetação de gramíneas e/ou leguminosas, cuja altura pode variar de } \\
\text { alguns decímetros a alguns metros. }\end{array}$ \\
\hline Mata nativa & $\begin{array}{l}\text { Área em que a vegetação nativa está preservada, com presença de vegetação arbórea } \\
\text { densa. }\end{array}$ \\
\hline
\end{tabular}

Fonte: IBGE (2012), adap. pelos autores.

O reservatório Riacho da Cruz II é responsável pelo abastecimento público dos municípios de Riacho da Cruz, Viçosa e Portalegre e, portanto, usos considerados inadequados podem influenciar diretamente na qualidade dessa reserva, assim como, na disponibilidade hídrica e distribuição.

A área urbana do município teve seu crescimento nas imediações do barramento sendo possível observar áreas urbanizadas nas proximidades da margem esquerda do reservatório. A construção do reservatório foi anterior a emancipação de Riacho da Cruz como município, em 1962. Assim, a cidade teve seu desenvolvimento ligado ao reservatório ao longo do tempo (FREITAS; GUEDES; COSTA, 2016), mudando suas características de localizado em área rural para urbana (WAGNER; KUMAR; SCHNEIDER, 2013).

Apesar da área urbana não foi observada presença de lixo na lâmina d'água e no entorno, ou mesmo queimadas, fato muito comum em outros mananciais (FONTES; QUEIROZ, 2015). Entretanto, a presença urbana no entorno do reservatório requer planejamento e gestão, referente a sua interferência na dinâmica natural do recurso hídrico, na sua relação com a captação e escoamento, o descarte dos resíduos sólidos, e especulação imobiliária (WAGNER; KUMAR; SCHNEIDER, 2013).

Conforme observado por Freitas, Guedes e Costa (2016), famílias residentes no entorno do reservatório utilizam a área para culturas temporárias nos períodos de precipitações e nas áreas de vazantes ${ }^{1}$, onde a produção é realizada como fonte de renda monetária e não monetária, com a comercialização do excedente para as regiões circunvizinhas.

1 As vazantes "são (...) os terrenos na margem dos açudes e lagoas (bem como dos leitos dos rios) que são inundados pelas águas durante a época chuvosa e vão sendo descobertos progressivamente durante a época seca" (MOLLE; CADIER, 1998, p. 135). 
Dentre as classes identificadas, a cultura temporária está concentrada na margem esquerda do reservatório, próximo a comunidade Aracajú e as demais residências rurais (FREITAS; GUEDES; COSTA, 2016). Apresenta uma produção anual de milho, feijão e sorgo, nas áreas próximas as residências rurais, nos períodos de precipitações; e de batata, jerimum e capim nas áreas do reservatório que ficam descobertas com a vazante. $\mathrm{Na}$ margem esquerda do reservatório foram observados plantios de hortaliças e plantas ornamentais. Essa é uma forma de agricultura familiar agregadora de renda para as famílias (CAPOANE; SANTOS, 2012). Hortas orgânicas são essenciais para a alimentação humana, assegurando segurança alimentar (BRASIL, 2006), mas cabe destacar que a produção nãoorgânica das culturas temporárias, especialmente em áreas próximas a reservas hídricas, trazem o risco de contaminação com agrotóxicos.

A cultura permanente está localizada na margem esquerda do reservatório próximo a comunidade Aracajú, sendo essa predominantemente de cajueiro. Essa cultura está voltada para exportação, regional e nacional, principalmente nos municípios circunvizinhos.

A vegetação rasteira está localizada nas duas margens do reservatório e nas imediações do barramento, próxima a área urbana do município apontando para a retirada da vegetação nativa. Nos estudos de Bezerra Jr. e Guedes (2016), nas proximidades da reserva é observada a importância das áreas de vegetação rasteira, destacando-se sua relevância, por ser caracterizada pela rápida reposição natural de gramíneas utilizadas para pastagem e, posteriormente a área é utilizada para culturas temporárias.

A classe 'Áreas sem cobertura', embora pouco significativas em área, destaca-se na paisagem pela presença do solo total ou parcialmente exposto, ocasionando impactos como assoreamento pelo carreamento de partículas de solo para o reservatório, com todos os compostos anexados durante os processos antrópicos como agrotóxicos, salinidade, chorume, entre outros (BEZERRA JR; GUEDES; COSTA, 2016).

Em relação a mata nativa, essa demonstra-se bem preservada. A proteção e conservação das matas naturais no entorno de corpos hídricos é relevante para a qualidade ambiental das reservas, preservando as margens de assoreamento (ROSA et al., 2015).

A construção de reservatórios, de pequeno, médio e grande porte, no semiárido, proporcionou de forma desordenada de barramentos nas áreas de drenagem dos rios e riachos, sem contar com planejamento e gestão das áreas cobertas pela lamina d'água e pelo desmatamento das matas ciliares no entorno. Assim, no entorno do reservatório, foram observados pequenos barramentos ocupando $0,62662 \%$ da área do entorno e correspondendo a 02 (dois) reservatórios de pequeno porte localizados em áreas de propriedades particulares em ambas as margens.

Guedes e Costa (2017) destacam também, por meio da utilização de imagem de satélite, a discussão referente a partes dos rios que são barrados, na construção de pequenos barreiros, e que estes podem influenciar na qualidade e quantidade do reservatório utilizado para o abastecimento hídrico. E, a presença de pequenos reservatórios próximos aos de abastecimento hídrico são evidentes na região, estudos de Freitas, Guedes e Costa (2015) também aponta a existência e alerta para possíveis mudanças no ambiente, quando são construídos sem planejamento e gestão dos possíveis problemas que possam causar. 
A comunidade Aracajú é a mais importante da área rural do município, onde grande parte das famílias mantém uma relação de proximidade ao manancial. Comunidades no entorno de reservatório superficiais de abastecimento possuem papel importante na dinâmica do ambiente, e Guedes e Amaral (2015; 2017) introduzem a percepção como forma de compreender como os usos e ocupação foram desenvolvidos e as mudanças advindas. A agricultura familiar está presente na comunidade Aracajú, na forma de produção em vazantes.-

Igualmente ocorre extração de areia, próximo a margem direta do reservatório. Embora contribua com a economia do município, essa atividade causa impacto no ambiente, uma vez que interfere no balanço de sedimentos no canal fluvial. A falta de fiscalização e/ ou gestão e planejamento inadequados dessa atividade pode interferir na qualidade ambiental do reservatório, principalmente na capacidade de acumulação do volume hídrico (OLIVEIRA; MELLO, 2007).

\section{CONSIDERAÇÕES FINAIS}

O reservatório Riacho da Cruz II como reserva hídrica municipal de Riacho da Cruz, Viçosa e Portalegre, referentes aos uso e ocupação do entorno, demonstrou-se como uma reserva que influencia diretamente as questões sociais e econômicas, por meio da visualização de culturas permanentes e temporárias no seu entorno.

Entretanto, é possível alertar sobre os usos e manejos impróprios referentes a legislação vigentes, uma vez que há existência de áreas descobertas e vegetação rasteira nas duas margens do reservatório, ações que podem ocasionar a longo prazo assoreamento do reservatório, no qual a quantidade e qualidade dessa reserva será alterada, e assim, ter reflexos no campo social e econômico da região.

Como também, foi possível observar a presença de área urbana no entorno do reservatório, trazendo as relações antrópicas desenvolvidas nesses, e suas características como a pavimentação do solo, escoamento superficial, interferências no processo de fotossíntese, entre outros, para a dinâmica ambiental de áreas de reservas hídricas, possibilitando a mudança e impactos nessas áreas.

Mesmo com a presença de áreas descobertas no entorno do reservatório é relevante afirmar a importância da faixa da área de mata nativa, que se apresenta como a classe de maior porcentagem no mapeamento, também como suporte natural para sua qualidade demonstrando sua importância atual e sua necessidade de preservação e conservação.

Assim, como medidas mitigadoras para possíveis problemas ambientais da área está a gestão participativa, onde a comunidade juntamente com o poder público do município e do Estado, desenvolvam projetos referentes ao reflorestamento da APP do reservatório. A produção de mudas de espécies nativas e sua inserção auxiliariam na qualidade ambiental do reservatório, além da construção de um saber social em relação a estabilidade natural e social, por meio da interligação e afetividade da população local com a reserva em questão. 
Assim, o uso e o ocupação do entorno de áreas hídricas interferem em sua qualidade ambiental, tornando-se necessária, dessa forma, utilizando-se da legislação vigente para planejar e gerir os usos desses, manejando-os de forma a não interferir em sua estabilidade natural, como também no desenvolvimento socioeconômico.

\section{REFERÊNCIAS}

BEZERRA JR., A.; GUEDES, J.A. Caracterização e análise do uso e ocupação da terra no entorno do reservatório Santana, Rafael Fernandes/RN. Revista Okara, João Pessoa, v.10, n.3, p.517-530, 2016. Disponível em: <www.periodicos.ufpb.br/index.php/okara/article/download/28365/16852> Acesso em: 03 abr. 2017.

; COSTA, L.B. Análise do uso e ocupação da terra no reservatório público do município de Água Nova-RN. In: ALVES, L. S. F.; CARNEIRO, R. Desafios da gestão dos recursos hídricos no estado do Rio Grande do Norte [e-book]. Natal: CCHLA, 2016. p.227-237.

BRITO, R.H.L.; GUEDES, J.A. Uso e ocupação das terras do entorno do reservatório Maretas, Rafael Fernandes, RN. In: CONGRESSO BRASILEIRO DE EDUCAÇÃO AMBIENTAL E APLICADA, 5. 2016. Anais... Fortaleza, 2016. 11 p.

BRASIL, Lei $\mathbf{N}^{\circ}$ 9.433, de 8 de janeiro de 1997. Dispõe sobre a forma de usos dos recursos hídricos e sobre ações que possam afetar a quantidade e qualidade da água. Disponível em: <http:/ /www.planalto.gov. br/ccivil_03/leis/L9433.htm> Acesso em: 15. mar. 2016.

Lei n. 11.346, de 15 de setembro de 2006. Cria o Sistema Nacional de Segurança Alimentar e Nutricional. SISAN com vistas em assegurar o direito humano à alimentação adequada e dá outras providências. Disponível em: <http://www4.planalto.gov.br/consea/conferencia/documentos/lei-deseguranca-alimentar-e-nutricional> Acesso em: 18 set. 2017.

Lei Florestal n. 12.651, de 25 de março de 2012. Dispõe sobre a proteção da vegetação nativa; altera as Leis $\mathrm{n}^{\circ}$ s 6.938, de 31 de agosto de 1981, 9.393, de 19 de dezembro de 1996, e 11.428, de 22 de dezembro de 2006; revoga as Lei $\mathrm{n}^{\circ}$ s 4.771, de 15 de setembro de 1965, e 7.754, de 14 de abril de 1989, e a Medida Provisória $n^{\circ}$ 2.166- 67, de 24 de agosto de 2001; e dá outras providências. Câmara dos Deputados, Brasília, DF, 25 mai. 2012. Disponível em: <www.planalto.gov.br/ccivil_03/_ato2011-2014/2012/lei/112651.htm> Acesso em: 25 jan. 2017.

CAPOANE, V.; SANTOS, D.R. Análise qualitativa do uso e ocupação da terra no assentamento Alvorada, Júlio de Castilhos - Rio Grande do Sul. Revista NERA, Presidente Prudente, v.15, n.20, p.193-205, jan./jun. 2012. Disponível em: <www.mstemdados.org/sites/default/files/1856-5502-1-PB.pdf> Acesso em: 10 fev. 2017.

CPRM. Serviço Geológico do Brasil. Projeto Cadastro de Fontes de Abastecimento por Água Subterrânea. Diagnóstico do município de Riacho da Cruz. Estado do Rio Grande do Norte. Recife, 2005.

CUNHA, L.H.; COELHO, M.C.N. Política e gestão ambiental. In: CUNHA, S.B.; GUERRA, A.J.T. A questão ambiental: diferentes abordagens. 5 ed. Rio de Janeiro: Bertrand, 2009. p.43-79.

DIAS, R. Gestão ambiental: responsabilidade social e sustentabilidade. São Paulo: Atlas, 2009.

DINIZ, F.O.; MEDEIROS FILHO, S.; BEZERRA, A.M.E.; MOREIRA, F.J.C. Biometria e morfologia da semente e plântula de oiticica. Revista Verde, Pombal, v.10, n.2, p.183-187, abr./jun. 2015. Disponível em:<https://www.researchgate.net/publication/283760582_Biometria_e_morfologia_da_semente_e_ plantula_de_oiticica> Acesso em: 23 maio 2016.

FREITAS, F.W.S.; GUEDES, J.A.; COSTA, F.R. Análise socioambiental do reservatório público do município de Riacho da Cruz (RN). Revista Geotemas, Pau dos Ferros, v.6, n.1, p.03-18, jan./jul. 2016. Disponível em: <http://www2.uern.br/index.php/geotemas/article/view/1742> Acesso em: 15 mar. 2016.

Qualidade ambiental do reservatório Passagem, Alto Oeste Potiguar. Revista 
Geotemas, Pau dos Ferros, v.5, n.2, p.31-41, jul./dez. 2015. Disponível em: <http://ojs.uern.br/index. php/geotemas/article/view/1652> Acesso em: 15 mar. 2016.

FONTES, O. L.; QUEIROZ, A.F. Uso e ocupação do solo nas margens do Açude Flechas no município de José da Penha/RN. Revista Geotemas, Pau dos Ferros, v.5, n.2, p.3-17, jul./dez., 2015. Disponível em: <http:/ / periodicos.uern.br/index.php/geotemas/article/view/1331> Acesso em: 15 mar. 2016.

GUEDES, J.A.; AMARAL, V.S. Percepção ambiental das comunidades residentes no entorno do reservatório Tabatinga, Macaíba/RN. Sociedade e Território, Natal, v.27, n.1, p.117-137, jan./jun., 2015. Disponível em: <https:// periodicos.ufrn.br/sociedadeeterritorio/article/viewFile/5089/5388> Acesso em: 25 abr. 2017.

Reservatório Tabatinga: a percepção de moradores da área urbana da cidade de Macaíba RN. Geosul, Florianópolis, v.32, n.63, p.139-158, jan./abr. 2017. Disponível em: <https:/ periodicos.ufsc. br/index.php/geosul/article/download/41208/34435> Acesso em: 12 maio 2017.

; COSTA, F.R. Qualidade ambiental de dois reservatórios públicos na região do Alto Oeste Potiguar (RN/Brasil). Revista GeoInterações, Assú, v.1, n.1, p.03-16, jan./jul. 2017. Disponível em: <http://ojs. uern.br/index.php/geointeracoes/article/view/2177> Acesso em: 10 set. 2017.

IBGE - Instituto Brasileiro de Geografia e Estatística. Manual técnico de uso da terra. 3 ed. Rio de Janeiro, 2012. Disponível em: <https://biblioteca.ibge.gov.br/visualizacao/livros/liv81615.pdf > Acesso em: 10 fev., 2016.

IBGE - Instituto Brasileiro de Geografia e Estatística. Perfil do município de Riacho da Cruz, 2015. Disponível em: <http://cidades.ibge.gov.br/xtras/perfil.php?lang=\&codmun=241070\&search=riogrande-do-norte | riacho-da-cruz> Acesso em: 16 ago. 2016.

KORMONDY, E.J. Recursos naturais e ecologia de comunidades. In: Atheneu, 2002. p.253-288.

Ecologia humana. São Paulo:

LOPES, E.S.; SAMPIETRO, J.A.; LOMBARDI, K.C.; DIAS, A N. Avaliação da umidade na compactação do solo submetido ao Tráfego de máquinas de colheita florestal. Revista Árvore, Viçosa, v.35, n.3, p.659-667, 2011. Disponível em: <http:/ / www.redalyc.org/html/488/48819946010/> Acesso em: 16 mar. 2016.

MAURO, C.A.D. Conflitos pelo uso da água. Caderno Prudentino de Geografia, Presidente Prudente, n.36, p.81-105, 2014. Disponível em: <http://revista.fct.unesp.br/index.php/cpg/article/view/3174> Acesso em: 16 mar. 2016.

MOLLE, F.; CADIER, E. Manual do pequeno açude. Recife: SUDENE-DPG-PRN-DPP-APR, 1992.

NASCIMENTO, F.E.; GUEDES, J.A. Qualidade ambiental do reservatório Cajá, município de Taboleiro Grande (RN). Revista Tamoios, São Gonçalo, v.12, n.1, p.130-143, jan./jun. 2016. Disponível em: <http:// www.e-publicacoes.uerj.br/index.php/tamoios/article/view/19610> Acesso em: 4 out. 2016.

OLIVEIRA, F.L.; MELLO, E.F. A mineração de areia e os impactos ambientais na bacia do rio São João, RJ. Revista Brasileira de Geociências, São Paulo, v.37, n.2, p.374-389, jun. 2007. Disponível em: <http:/ / www. ppegeo.igc.usp.br/index.php/rbg/article/view/9280> Acesso em: 16 mar. 2016.

PARANHOS FILHO, A.C.; MIOTO, C L.; MARCATO JR, J.; CATALINI, T.G.T. (Orgs.). Geotecnologias em aplicações ambientais. Campo Grande: UFMS, 2016.

PROCESSAMENTO DIGITAL. Composição colorida da imagem de satélite Sentinel-2. 2016. Disponível em: $\quad$ <http://www.processamentodigital.com.br/2016/09/04/qgis-composicao-colorida-rgb-paraimagens-sentinel-2>. Acesso em: 20 jan. 2016.

ROSA, A.H. et al. Diagnóstico ambiental e avaliação de uso e ocupação do solo visando a sustentabilidade da represa de Itupararanga, importante área da bacia do médio tietê. In: POMPEO, M. et al. Ecologia de reservatório e interfaces. São Paulo: Instituto de Biociência da Universidade de São Paulo, 2015. p.213-231.

SEMARH - Secretária de Estado do Meio Ambiente e Recursos Hídricos. Ficha técnica do reservatório Riacho da Cruz II. Disponível em: <http://servicos.searh.rn.gov.br/semarh/sistemadeinformacoes/ consulta/cResFichaTecnica.asp?IdReservatorio=12> Acesso em: 20 ago. 2016.

TUNDISI, J.G. et al. Limnologia de águas interiores: impactos, conservação e recuperação de ecossistemas aquáticos. In: REBOUÇAS, A.C; BRAGA, B.; TUNDISI, J.G. (Org.) Águas doces no Brasil: capital ecológico, 
uso e conservação. 3 ed. São Paulo: Escrituras, 2006. p.203-240.

VENTURI, L.A.B. Recurso natural: a construção de um conceito. GEOUSP - Espaço e Tempo, São Paulo, n.20, p.9-17, 2006.

WAGNER, P.D.; KUMAR, S.; SCHNEIDER, K. An assessment of land use change impacts on the water resource of the Mula and Mutha Rivers catchment upstream of Pume, India. Hydrology and Earth System Sciences, n.17, p.2233-2246, 2013. Disponível em: <https:/ / www.hydrol-earth-syst-sci.net/17/2233/2013/ hess-17-2233-2013.pdf> Acesso em 16 mar. 2016.

Data da submissão: 14/jul./2017

Data do aceite em: 04/jun./2018 